\title{
深基坑支护施工技术在土建基础施工中的应用
}

\author{
王鹏飞 \\ 中国电子系统工程第二建设有限公司，江苏 无锡 214000
}

[摘要]科学技术的快速发展, 为各个领域的发展壮大创造了良好的基础。在这种形势下, 建筑行业内各个施工技术也在不断 的发展, 深基坑支护技术已经发展成为了土建工程施工中的核心技术，在土建工程施工过程中的运用十分的频繁。但是就深 基坑支护施工技术的实际情况来说, 并没有达到成熟的状态, 其中还存在诸多的问题需要我们进行有效的解决, 从而推动深 基坑支护施工技术不断优化完善，为建筑行业的稳定健康发展创造良好的基础。

[关键词]深基坑支护; 土建基础施工; 应用

DOI：10.33142/aem.v2i3.1813 中图分类号: TU753 文献标识码: A

\section{Application of Deep Foundation Pit Support Construction Technology in Civil Construction Foundation Construction}

\author{
WANG Pengfei
}

China Electronics System Engineering No.2 Construction Co., Ltd., Wuxi, Jiangsu, 214000, China

\begin{abstract}
The rapid development of science and technology has created a good foundation for the development and growth of various fields. Under this situation, various construction technologies in the construction industry are also constantly developing. Deep foundation pit support technology has developed into a core technology in civil engineering construction, and is frequently used in civil engineering construction. However, in terms of the actual situation of deep foundation pit support construction technology, it has not reached a mature state, and there are still many problems that need to be solved effectively, so as to promote the continuous optimization and improvement of deep foundation pit support construction technology, and create a good foundation for the stable and healthy development of the construction industry.
\end{abstract}

Keywords: deep foundation pit support; civil foundation construction; application

\section{引言}

社会的快速发展带动了整个土建工程的稳步发展, 土建工程所具有的突出特点就是施工工作量较为巨大, 施工难 度较高, 并且危险系数较高, 所以近年来在土建工程施工技术不断发展的过程中, 人们对安全防护工作的重视度也在 逐渐的提升。房屋建筑发展趋势正在朝着高端化的方向迈进, 这样也就对土建基坑施工工作带来了诸多的困难, 为了 有效的提升施工的安全性, 最为重要的就是要针对基坑施工工作进行合理的安全防护。

1 土建基础施工环节中深基坑支护的主要类型

1.1 排桩支护

完整的排桩柱结构通常都是由防渗帷幕、支撑、支护柱等多个结构组合而成的, 并且结构形式涉及到: 矩形、丁 字形、三角形等布置方式。支护结构都是由冠梁与排桩等组成, 利用钢筋混凝土进行施工建造, 就整个结构的受力情 况来说, 排桩的支护特点主要存在下面几个方面: 首先, 结构整体受力较为均衡, 特别是利用连梁之后, 针对土体形 变以及排桩结构起到了良好的控制效果。其次, 是整个结构稳定性较强, 从而为支护结构的刚度保证起到了积极的影 响。最后, 是支护士拱效应较强, 侧向土压力不断的提升, 支护作用的效果也会随之增加。

\section{2 钢板桩支护}

支护结构往往都是临时性搭建的辅助结构, 所以需要对其经济性和安全性加以重点关注。钢板桩支护方式不但施 工效率较高, 并且成本较少, 适合大范围的加以运用。在针对钢板桩支护系统进行设计工作的时候, 应该针对各项重 点参数进行准确的计算。在实际开展施工工作的时候, 钢板墙体结构需要由锁口或钳口热轧型材料的钢板桩逐个链接 组合认成，这种类型的结构在遮挡水土方面具有非常良好的作用。

\section{3 土钉支护}

土钉支护技术其实质就是利用专业的技术将天然土体与钢筋网喷射混凝土进行结合, 最终构成能够满足力学要求 的土钉墙结构, 并将这一结构用作抵挡墙体后的土方给予的压力, 保证墙体挖掘面与基坑边坡结构具有良好的稳定性。 在实际开展施工工作的时候, 往往需要利用到大量的土钉, 一旦某个土钉丧失效力, 也不会对整个支护结构造成不良 
影响。并且物料使用量较少, 施工整体花费较少, 施工持续时间较短, 特别是在沙土或者是硬黏土等特殊性质的土质 环境下，利用这项技术的效果最好。施工工艺涉及到测量放样、挖掘基坑、安设土钉、灌注混凝土等等 ${ }^{[1]}$ 。

\section{4 地下连续墙}

地下墙体结构施工工序持续时间较短, 墙体结构载荷能力较强, 并且具备良好的抗渗透能力。但是在进行地下连 续墙体施工工作的时候, 因为极易受到外界不良因素的影响, 所以施工成本需要加以合理的管控。地下连续墙体结构 通常都是被建造在地下水位影响程度较大的粘土层或者是深层土壤层之中, 在正式开始施工工作之前, 我们需要对施 工现场的各方面条件进行全面的勘察, 结合获得的信息数据制定出切实可行的施工方案, 保证工程施工的质量。

\section{2 深基坑支护技术应用实际情况}

\section{1 压力精确度不足}

土建深基坑施工工作需要借助支护结构进行防护, 在正式开始支护结构施工工作之前, 要针对土建施工结构各项重点参 数进行精准的计算, 结合各项信息数据来进行深基坑支护施工工作，保证施工的效果。但是在开展各项数据计算工作的过程 中, 因为往往会遭到外界各种因素的影响, 所以无法从根本上对数据的准确性加以保证, 再加上库伦公式的运用往往也需要 土体结构的参数来加以纠正。这样就会造成施工准准确度较差的不良结果, 最终导致压力准确度不足的情况发生 ${ }^{[2]}$ 。

\section{2 施工作业存在误差}

因为经常会受到各种外界不良因素的影响, 所以工程设计与实际施工工作之间极易出现差异性, 诸如: 环境因素, 地质因素等等, 并且也会对后期的施工工作的顺利开展造成诸多的阻碍。所以在实际开展工程施工工作的时候, 我们 需要综合各方面实际情况来对设计图进行完善, 为施工工作的有序开展创造良好的基础。其次, 土建工程施工人员的 专业能力和综合素质也与施工的质量和效果存在密切的关联, 如果施工工作人员具备良好的专业能力和丰富的工作经 验, 那么在保证施工工作的高效开展方面能够起到积极的影响。如果工程所处地区地质结构属于软土地质, 那么就会 对深基坑支护施工工作带来一定的困难，所以需要进行前期的加固处理工作，否则可能会引发塌陷的情况发生。

\section{3 空间设计有偏差}

就现如今土建工程基础结构施工工作实际情况来说，深基坑空间设计整体效果较差，空间设计存在一定的偏差， 很多的深基坑都呈现出了两边高, 中间凸起的情况, 施工难度较大。在针对深基坑结构实施设计工作的时候, 通常都 会实施无凸起面的设计, 并且设计图中的深基坑的结构规模较大, 空间设计与实际施工情况也会出现一定的差异, 最 终会对深基坑施工工作产生诸多的阻碍。这就充分的说明了, 单纯的利用设计图纸来实施深基坑的支护施工工作并不 适合当前的土建工程, 所以我们需要结合工程各方面实际情况, 科学合理的对深基坑的支护形式进行选择 ${ }^{[3]}$ 。

\section{4 岩土取样不全面}

在实际开展深基坑支护施工工作之前, 需要安排专业人员进行岩土结构的取样工作, 并利用专业仪器设备对土质 和土壤情况进行检测，确保选择使用的施工机械和设备能够满足深基坑支护施工的时机需要。

\section{3 深基坑支护施工技术的具体应用}

\section{1 挖掘土方}

深基坑支护工程中的首要工作就是进行土方挖掘步骤, 工作人员应该将挖出的土壤及时运送到深基坑工程地点以 外, 注意施工现场的清理, 在具体的挖掘施工中, 如果遇到线缆或是管道, 应该立即停止挖掘施工, 并与有关部门进 行协调处理问题，保证土建工程能够在后续正常进行，避免造成其他工程的危害 ${ }^{[4]}$ 。

\section{2 基坑支护结构的监测}

在整个土建基础施工的过程中, 最重要的就是对深基坑支护施工的监督和检测, 只有对施工阶段的每个细节进行 严格管控, 才能有效提高深基坑支护施工技术的质量, 并为后续施工工作创造良好基础。应该对深基坑支护结构的硬 度、位置、以及变形程度进行适当监督检查, 一旦出现问题应该及时上报并解决, 防止时间长导致不合格的深基坑结 构凝固, 影响施工的进度, 及时的监测保证深基坑支护施工的效率 ${ }^{[5]}$ 。

\section{4 总结}

建筑企业间的市场竞争越发激烈, 确保土建基础施工质量, 还需加强基坑支护施工基础的完善程度, 及时分析支 护技术应用中的问题, 加强经验总结, 制定可行的施工方案, 确保土建基础施工成效。在规范展开深基坑支护施工方 法与工序的同时，应当加强技术创新改进，营造更大的效益，提供建筑安全保障。

\section{[参考文献]}

[1]徐峰.深基坑支护施工技术在土建基础施工中的应用 [J]. 居舍, 2020(02): 75 .

[2]刘文应.土建基础施工中深基坑支护施工技术应用 [J].建材与装饰, 2020(01): 22-23.

[3] 朴金海,黄伟宏.土建基础施工中深基坑支护施工技术分析 [J].居舍,2019(33): 63.

[4]高县卫.土建施工中深基坑支护施工技术的运用探究 [J]. 建材与装饰, 2019(28): 12-13.

[5]王成。深基坑支护施工技术在土建基础施工中的应用 [J]. 工程技术研究, 2019,4(16): 51-52.

作者简介: 王鹏飞（1990.11.20-), 男, 佳木斯大学, 土木工程, 中国电子系统工程第二建设有限公司。 